\title{
The Tragedy of the Commons and Inflation Bias in the Euro Area
}

\author{
Valeriya Dinger Sven Steinkamp Frank Westermann* \\ Institute of Empirical Economic Research \\ Osnabrueck University, Germany \\ Rolandstr. 8, 49069 Osnabrück
}

Last Revision: December 04, 2012

First Draft: October 31, 2012

\begin{abstract}
Central bank credit has expanded dramatically in some of the euro area member countries since the beginning of the financial crisis. This paper makes two contributions to understand this stylized fact. First, we discuss a simple model of monetary policy that includes (i) a credit channel and (ii) a common pool problem in a monetary union. We illustrate that the interaction of the two elements leads to an inflation bias that is independent of the standard time-inconsistency bias. Secondly, we present empirical evidence that is consistent with the view that national central banks in the euro area have indeed followed an independent monetary policy. We show that after 2007, central bank credit has been highly correlated with unemployment, but not with inflation in the respective countries.

JEL: E52, E58, H41; Keywords: Tragedy of the Commons, Inflation Bias, Credit Channel, TARGET2, Euro Area
\end{abstract}

\footnotetext{
${ }^{*}$ Correspondence: frank.westermann@uos.de
} 


\section{Motivation}

Central bank credit has expanded on an order of magnitude that is unprecedented in the post-war history of Europe. In countries with a negative output shock - Greece, Italy, Ireland, Portugal and Spain - it has increased by more than $1000 \%$ since the beginning of 2007 . In this paper, we review the institutional arrangements in the euro area and present a theoretical model, as well as empirical evidence, that help to understand this stylized fact. We argue that the expansion was facilitated by a fragmentation of the ECB's monetary policy that is implemented by the national central banks.

The institutional changes that set the stage for a classical tragedy of the commons-dilemma have started in 2007, when the ECB introduced the TARGET2 clearing system. ${ }^{1}$ This clearing system linked the money markets across Europe, creating a common pool of money demand to which all central banks had access. ${ }^{2}$ Furthermore, the ECB, which in principle controls monetary policy, announced a "full allotment" policy. Under this policy, private banks had unlimited access to central bank credit, provided that they were able to pledge collateral that was acceptable to the ECB. The national central banks (NCBs) finally gained control over monetary policy in their jurisdiction, when the ECB relaxed their collateral standards. An important institutional aspect is that the NCB's assess the quality of this collateral. It is thus the implementation of monetary policy, not the decision making, that is the source of the common pool problem. ${ }^{3}$

To motivate why such an institutional setting leads to an additional inflation bias in monetary policy, we set up a simple partial-equilibrium model that starts with a standard central bank utility function, including the output gap and inflation. We add two non-standard elements to this model: (i) A credit channel of monetary policy. We assume that the national central banks can have a direct impact on the economy by extending central bank credit to relax credit constraints in the domestic economy. (ii) We assume that there is a common pool problem in a monetary union of the following type: Central banks can extend credit to private banks in their jurisdiction. However, the associated increase in money supply is not confined to lead to inflation in this particular country. There exists a single money market in the currency union, thus prices will increase in all countries. By extending central bank credit the NCB's reap the full marginal benefit of their policy, but face only the average cost in terms of inflation.

We show in the model section that there is an inflation bias resulting from this common pool problem that is independent of the standard time-inconsistency bias. ${ }^{4}$ Our model builds on an earlier literature on inflation bias in currency

\footnotetext{
${ }^{1}$ The tragedy of the commons interpretation was also given in Tornell \& Westermann (2012a, 2012b) and Tornell (2012).

${ }^{2}$ See Sinn \& Wollmershäuser (2012) and Garber (1999), as well as Section 2 of this paper for more institutional details and the economic interpretation of TARGET2 balances.

${ }^{3}$ See von Hagen \& Süppel (1994) for an analysis of a common pool problem in the central bank decision making.

${ }^{4}$ See e.g. Barro \& Gordon (1983) and Walsh (2010).
} 
unions, in particular Aizenman (1992) and Casella (1992). In their papers, the inflation bias arises from externalities among jurisdictions that are competing for seigniorage and the inflation tax. On an abstract level, our model can be viewed as a simple partial-equilibrium representation of these ideas. Furthermore, it takes special features of the current Euro-crisis into account: (i) the central banks objective of achieving financial stability - i.e. avoiding the cost of bank closures - and (ii) the credit crunch suffered in several European countries after the $2007 / 8$ financial crisis. ${ }^{5}$

In the empirical section of the paper, we review some stylized facts and estimate central bank reaction functions in a formal regression framework. Among the stylized facts, three observations stand out: First, countries that recently experienced a negative output shock have increased central bank credit substantially. Furthermore, this central bank credit did not stay within the national borders of the respective country. It has been wired to other countries via the TARGET2 clearing system to buy goods and assets abroad and to repay international loans, thus increasing the money supply throughout the whole monetary union. The absolute values of TARGET2 liabilities are nearly identical to the increase in central bank credit. Secondly, we illustrate that central bank lending already constitutes a substantial share of total lending in the countries in crisis. In the GIIPS countries (Greece, Ireland, Italy, Portugal and Spain), it has increased from $1.6 \%$ in 2007 to $16.4 \%$ in 2012 . Third, it has been highly correlated with unemployment rates since the 2007/8 financial crisis. Finally, it is remarkable that both, M1 and prices have increased only moderately in the countries that experienced the negative shock.

We formally evaluate these stylized facts in a panel-regression analysis of the determinants of central bank credit. In our benchmark regression, we estimate the link between central bank credit of each NCB and inflation as well as unemployment rates in their jurisdiction. We use the sample period from 2000 onwards and include a dummy variable for the post-2007 period. We find that prior to 2007 the central banks have reacted primarily to inflation. After 2007 , however, the inflation variable turns insignificant and the unemployment variable becomes significant instead. There has been an apparent change in the policy objective that is consistent with the timing of institutional changes and the predictions of the theoretical model presented above.

We test for robustness of our regression in several ways. First, we compare different starting dates for the regime shift that occurred sometime between the beginning of 2007 and October 2008. Secondly, we perform an outlier analysis, to make sure that none of the individual countries drive the results by themselves. Finally, we perform a range of different estimation methods, including 2 -stage least squares procedures that control for the potential endogeneity in our regressions. In all specifications, the apparent shift from inflation-targeting to unemployment-targeting remains largely unchanged.

In section 2 of the paper, we discuss in more detail the institutional arrange-

\footnotetext{
${ }^{5}$ Our model is also related to the competition among bank regulators modelled by Sinn (2003).
} 
ments. In section 3, we present the theoretical model. Section 4 presents stylized facts and the regression analysis. In section 5 , we relate our findings to previous studies in the literature. Section 6 concludes by pointing to concrete policy proposals that help to internalize existing externalities.

\section{Institutional framework of the Eurosystem}

The tragedy of the commons (or common-pool problem) describes a situation when multiple players operate in a framework where it is possible that each individual player extracts some benefits from exploiting a common pool of resources while paying only a portion of the costs. The key institutional questions that we review in this section are (i) what is the common pool that is overly used and (ii) why do national central banks have access to this common pool?

The common pool is the euro-area wide money demand. ${ }^{6}$ It has been created in several steps. First, the introduction of the euro itself eliminated exchange rate risks among member countries and created an integrated capital market. However, national central banks continued to exist and the ECB in Frankfurt centrally set the interest rate for all countries. The allocation of money creation by the different national central banks, until 2007, was mainly driven by the demand of private banks for central bank credit. This demand, however, was limited by the money demand in the respective country. This was changed when the TARGET2 clearing system was introduced that contained a so-called "real-time settlement system". In this settlement system, national central banks have the task to execute transfer payments, even before the incoming funds have arrived.

In principle this leads to imbalances, which last only for a few seconds. However, in the financial crisis, these balances have become more and more persistent, accumulating to substantial levels of claims and liabilities between the central banks of the Eurosystem (see Sinn \& Wolmershäuser (2011) and Garber (1998) for further details). With regard to the common pool problem, this meant the following: the national central banks where no longer limited by the demand for money in their own country, but instead they could service the entire euro-area wide demand for money. While the demand for money used for domestic purposes was small, the demand for money for the purpose of international transactions was and continues to be very large.

The second institutional question is how the national central banks gained access to this common pool. The classical perception of monetary policy operations within the EMU excludes this possibility. The ECB is supposed to provide uniform monetary policy by setting uniform interest rates and equal conditions for the access of banks from all participating countries to central bank funding. If this is indeed the case - as it was broadly the case until the end of 2007 - exploiting the common pools should be hardly possible for any individual member of the union.

\footnotetext{
${ }^{6}$ See also Tornell (2012) and Tornell \& Westermann (2012a).
} 
However, since 2007, individual countries gradually gained control over credit extension. To start with, the national regulators de facto decide on the list of banks eligible to receive central bank's funds. ${ }^{7}$ This is the case since the ECB declares all solvent banks eligible for central bank refinancing, but the definition by which banks are solvent or not is still made by the national financial regulation authorities. ${ }^{8}$ By not closing down virtually insolvent banks national authorities achieve at least two targets. First, they avoid both the political and economic costs of the liquidation of these banks. Second, they exploit the advantage of the fact that these banks' remaining assets - instead of being liquidated under the currently adverse conditions - can be used as collateral to generate increased central bank credit to the domestic banking sector. This is why the right of national regulators to decide on the solvency of the banks is an important determinant of the amount of central bank's credit to commercial banks.

Another important determinant of this amount is the gradual reduction of collateral standards by the ECB starting in October 2008. In fact, from the end of 2011, the European Central Bank has virtually given up control over the eligible collateral on the central banks refinancing operations. This fact is nicely illustrated by a Governing Council decision announced by the ECB on February 9th, 2012 which allows "specific national eligibility criteria and risk control measures for the temporary acceptance of additional credit claims as collateral in Eurosystem credit operations".

This decision puts the national central banks in charge of the decision about which assets can serve as eligible collateral and which cannot. The fact that the ECB does not want to control the quality of collateral is also illustrated by a most recent decision of the ECB announced on September 6th, 2012 which suspends the application of the minimum credit rating threshold in the collateral eligibility requirements. ${ }^{9}$

In sum, the volume of refinancing can significantly differ across countries. In the beginning of the crisis, this was due to a built-in flexibility under existing rules. But since the ECB's reduction of collateral standards, this expansion has been increasingly a result of the national central bank's policies. $54 \%$ of the total expansion occurred after December 8th, when the most significant drop in collateral standards was announced. The former ECB Chief Economist, Jürgen Stark, recently summarized these developments in the statement "The ECB is about to lose its ability to perform uniform monetary policy". ${ }^{10}$

\footnotetext{
${ }^{7}$ For the purpose of the subsequent analysis we can view central banks and national regulators as one entity. In the policy conclusions we highlight the need for both, a common regulation and a uniform catalogue of eligible collateral.

${ }^{8}$ See Tornell \& Westermann (2012a)

${ }^{9}$ This expansion of eligible collateral categories affects not only the volume of central bank's funding. In combination with the relatively rough grid of asset categories used for the determination of the collateral haircuts it also gives rise to substantial variation of the costs of central bank funding for banks from different countries. Given almost uniform haircuts for each asset category banks with more risky assets enjoy an advantage in the de facto costs of funding relative to banks with safer assets from the same haircut category.

${ }^{10}$ Frankfurter Allgemeine Zeitung, October 24, 2012.
} 


\section{A model of monetary policy with a credit chan- nel and a common pool problem}

In this section, we illustrate the effect of a common pool problem in a very simple model of monetary policy. We start from a standard loss function for the central bank (see e.g. Walsh (2010) and Barro \& Gordon (1983)) and add two new elements. First, we assume that there is a direct effect of central bank credit on output. This assumption can be motivated by the literature on the financial accelerator (Bernanke, Gertler \& Gilchrist (2000)) as well as the credit channel on monetary policy (Kashyap, Stein \& Wilcox (1993) and Tornell \& Westermann (2005)). Secondly, we assume that there is a common pool problem in the currency union as discussed above. Each individual central bank can extend credit to its banks. By doing so the central bank reaps the full benefits from this credit extension, but only bears the average loss in the form of the average inflation in the euro area.

\subsection{A single country}

Let us start with a single country as a point of reference, where only the credit channel is added to the standard model of the central bank's optimization problem. The notation of the model is as follows. The utility function of a national central bank is given by $U(y, \pi)$, where $y$ denotes production and $\pi$ denotes inflation. The utility function is taken from a standard textbook. The central bank gets positive utility from closing the gap between output $y$ and the exogenously given potential output $\overline{y_{n}}$. Furthermore, there is a quadratic loss from inflation. $\lambda$ denotes the weight attached by the central bank to closing the output gap.

$$
U(y, \pi)=\lambda\left(y-\overline{y_{n}}\right)-\frac{1}{2} \pi^{2}
$$

The production function consists of two components. First, the potential output, $\overline{y_{n}}$, and a cyclical component, $y_{c}$, that depends on the change of central bank credit in the economy, which in turn depends on the central banks supply of credit to commercial banks, $\Delta d$. This later term is kept very general and could take various functional forms. For the moment we only assume that the effect of central bank's credit on output is positive $\frac{\partial y}{\partial \Delta d}>0$.

$$
y=\overline{y_{n}}+y_{c}(\Delta d)
$$

In order to link this credit channel to money supply and inflation, we furthermore assume that the change in the monetary base is equal to the change in the amount of central bank's credit provided to the commercial banks: $\Delta m=\Delta d$, where $m$ denotes the monetary base (we thus abstract from other forms of monetary expansions that would for instance follow from explicit bond purchases of the central bank, as well as minimum reserve holdings). 
We further assume that inflation is a function of monetary base changes $\pi=\pi(\Delta m)$, where $\frac{\partial \pi}{\partial \Delta m}>0$. The value of this partial derivative depends on the money multiplier and in particular on the commercial banks' reserves with the central bank (e.g. the higher the propensity of commercial banks to distribute the funding received from the central bank to the non-financial sector). Since these are not at the core of the analysis presented here, we assume for simplicity that $\frac{\partial \pi}{\partial \Delta m}=1 .^{11}$

Lemma 1 In a single country there is an inflation bias of $\lambda \frac{\partial y}{\partial \Delta m}$

Proof. $\arg \max _{\Delta m} U=\lambda y_{c}(\Delta m)-\frac{1}{2}(\Delta m)^{2} ; \frac{\partial U}{\partial \Delta m}=\lambda \frac{\partial y}{\partial \Delta m}-\Delta m=0 ; \Delta m^{*}=$ $\lambda \frac{\partial y}{\partial \Delta m}$

The intuition for this result directly follows from the utility function of the central bank. Since inflation enters as a quadratic term, most functional forms for $y_{c}(\Delta d)$ will generate a positive equilibrium inflation. For instance if $y_{c}(\Delta d)$ is linear, the additional inflation would simply be a constant added to the term $\lambda$.

\subsection{A currency union}

In this section we now extend the model to a currency union, with $i=1, . ., n$ countries. In this currency union, each country has its own central bank utility function $U_{i}\left(y_{i}, \pi_{i}\right)$. This choice of utility function will be justified in the following empirical section. It also has a country specific production function $y_{i}$ and inflation rate, $\pi_{i}$. The monetary base in each country is denoted by $m_{i}$. Again, changes in the monetary base are equal to the changes in the credit provided by the central banks to the domestic banking system, $d_{i}$. In the utility and production functions we furthermore assume that the potential output is the same for all countries:

$$
\begin{gathered}
U_{i}\left(y_{i}, \pi_{i}\right)=\lambda\left(y_{i}-\overline{y_{n}}\right)-\frac{1}{2} \pi_{i}^{2} \\
y_{i}=\overline{y_{n}}+y_{c}\left(\Delta d_{i}\right)
\end{gathered}
$$

with $\frac{\partial y_{i}}{\partial \Delta m_{i}}>0$. The common pool problem in this setup follows from the fact that each country's inflation rate must be the same across countries: $\pi_{i}=\pi$. The additional money printed in one country, can be used to purchase goods in any other country. Due to the law of one price, however, the price level will be the same in all countries. ${ }^{12}$ Each country thus has the full marginal benefit of

\footnotetext{
${ }^{11}$ Abandoning this simplifying assumption leaves the qualitative results of the model unchanged as long as $\frac{\partial \pi}{\partial \Delta m}>0$.

${ }^{12}$ This assumption may be relaxed. It is sufficient to assume that domestic inflation costs do not rise proportionally to central bank credit for the inflation bias to occur.
} 
central bank credit extension that enters its production function, but faces only the average marginal cost that derives from inflation: $\pi=\frac{1}{n} \sum_{i=1}^{n} \Delta m_{i}$.

Proposition 2 In a currency union with a common pool problem, the inflation bias is larger than in a single country.

Proof. $\arg \max _{\Delta m_{i}} U_{i}=\lambda y_{i}\left(\Delta m_{i}\right)-\frac{1}{2}\left(\frac{1}{n} \sum_{i=1}^{n} \Delta m_{i}\right)^{2}$; In symmetric equilibrium: $\frac{\partial U_{i}}{\partial \Delta m_{i}}=\lambda \frac{\partial y_{i}}{\partial \Delta m_{i}}-\frac{1}{n} \Delta m_{i} ; \Delta m_{i}^{*}=n \lambda \frac{\partial y_{i}}{\partial \Delta m_{i}} ; n \lambda \frac{\partial y}{\partial \Delta m}-\lambda \frac{\partial y}{\partial \Delta m}=\frac{\partial y}{\partial \Delta m} \lambda(n-1)>0$

The intuition for our proposition follows from the tragedy of the commons. Each country has an incentive to exploit the credit channel effect of its central bank credit extension, but it only bears the average cost of such action. The temptation to extend central bank credit and to contribute to the average inflation rate is, therefore, extraordinarily high.

\section{Empirical relevance}

The simple model outlined above helps to explain the pattern of central bank credit expansion in the euro area since the beginning of the 2007/8 financial crisis. In this section, we document the recent development. We argue that it is consistent with the view that national central banks have indeed gained room to implement country specific monetary policy. We start by documenting three stylized facts ${ }^{13}$ and then conduct a more formal analysis of the central reaction functions in a regression analysis.

\subsection{Stylized facts}

1 Countries with a negative output shock have expanded central bank credit substantially

A remarkable feature of the financial crisis in Europe was that national central banks have expanded credit to domestic banks in an asymmetric pattern. While central banks in countries with negative output shocks have expanded credit to domestic commercial banks (in particular Greece, Ireland, Portugal and Spain), countries which did not experience such a negative shock kept their central bank's credit relatively constant or even reduced it. Figure 1 shows that the credit expansion in the crisis countries is unprecedented in post-war history. On average, it amounts to a more than $1000 \%$ increase in less than five years, or more than 800bn Euros in absolute terms. ${ }^{14} 15$ This phenomenon reflects

\footnotetext{
${ }^{13}$ See also Tornell \& Westermann (2012a) for an overview of some of these stylized facts.

${ }^{14}$ See Sachs, Tornell \& Velasco (1996) for the analysis of a similar pattern in Mexico 1994/5.

${ }^{15}$ Some expansion of central banks credit was also observed in countries without a negative output shock, however, in these countries the change in central banks credit was offset by an increase of commercial banks reserves with the central bank of a similar magnitude.
} 
in part the fact that in these countries the central bank was taking over the liquidity insurance role earlier provided by private interbank markets. In the presence of sharp reversals in private capital flows, they have replaced private capital by central bank credit.

The dashed series in Figure 1 illustrates that the money extended to the domestic banking system was not used to purchase goods or assets domestically, but rather financed international transactions. The TARGET2 balances measure the international balance of payments within the European Monetary Union (See Sinn \& Wollmershäuser (2012)). The fact that central bank's credit is used to facilitate transactions outside the individual country, but within the EMU, illustrates the spread of inflationary pressures generated by individual countries expansionary policy to other members of the Union.

Figure 1: Central Bank Credit and TARGET2 Balance

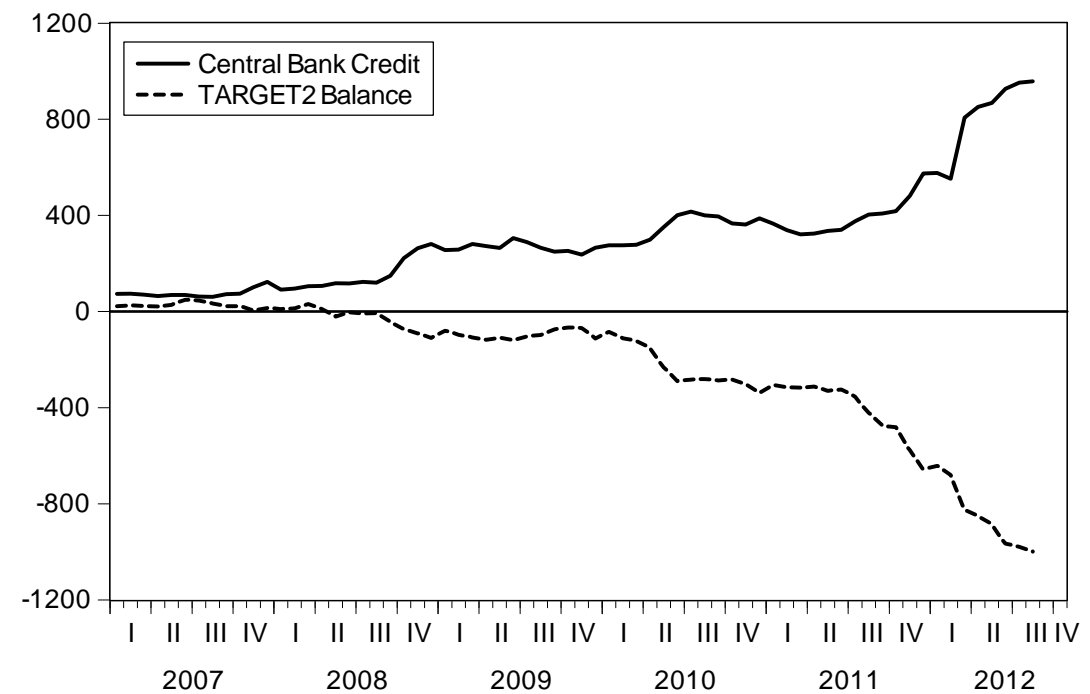

Notes: The figure shows the sum of central bank credit and the sum of claims/liabilities against the Eurosystem (TARGET2 balance) of the national central banks of Greece, Ireland, Italy, Portugal and Spain

(in bn €). Sources: International Financial Statistics, Euro Crisis Monitor

2 Private bank lending has increasingly been funded by central bank credit

Figure 2 shows that the commercial banks have funded a substantial share of their lending to the non-financial sector by credit from the central bank. The average share of total lending to the non-financial sector funded by central bank credit went up from around $1.6 \%$ in 2007 to $16.4 \%$ in the third quarter of 2012 . The dynamics of central bank's credit in the individual countries is illustrated in Figure 5 of the appendix. It shows that the issue is particularly severe in Greece and Ireland. The central banks thus acted to prevent a credit crunch that would have occurred without the intervention of the central banks, with 
potentially severe negative consequences for the real economy.

Figure 2: Ratio of Central Bank Credit to Private Bank Lending

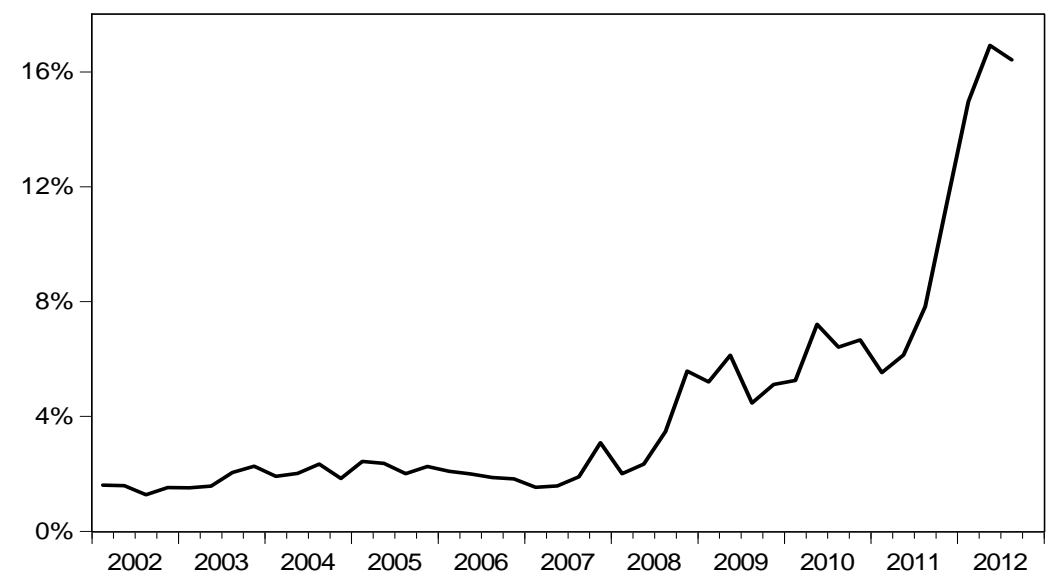

Notes: The figure shows the sum of central bank credit as percentage of total lending by other monetary financial institutions for the GIIPS countries (Greece, Ireland, Italy, Portugal and Spain). Source: International Financial Statistics

3 Central bank credit correlates positively with unemployment, but not with inflation

Figure 3 shows that the macroeconomic patterns in Europe are very much in line with the idea of an active central bank that follows an output/employment target. The dashed line in Figure 3 displays the average unemployment rate in Greece, Ireland, Italy, Portugal and Spain and the solid line traces the total central bank credit in these countries. From this figure, it appears that the central banks - although with some delay - are reacting to the domestic unemployment by extending credit to the private banks in their jurisdiction. Figure 4 in Appendix 2 of the paper shows that the same pattern also holds for each individual country. 
Figure 3: Central Bank Credit, Unemployment and Inflation

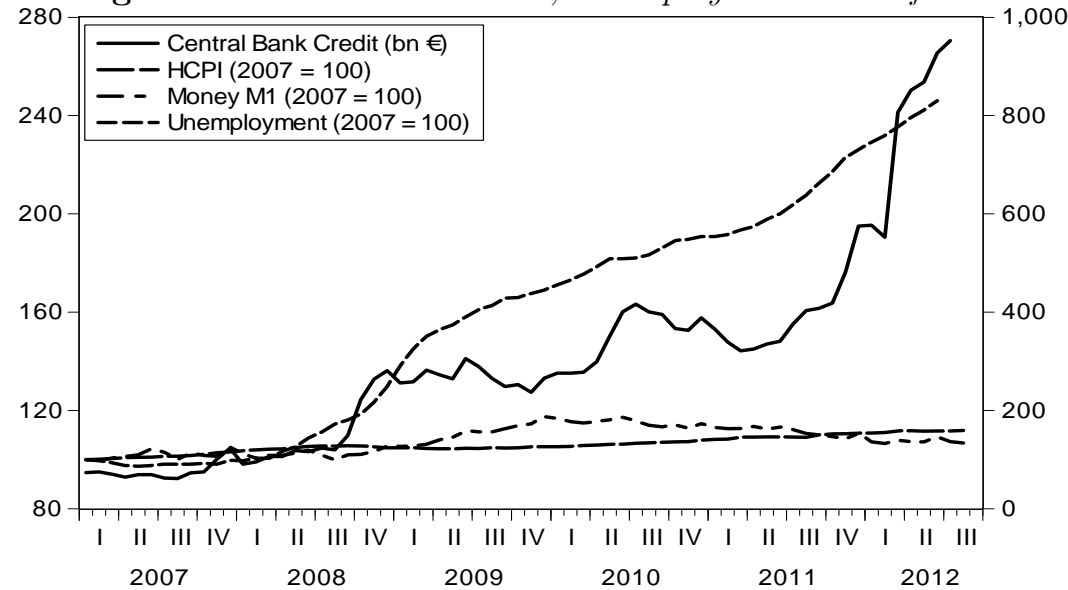

Notes: The figure shows the sum of central bank credit (bn $€$, right scale), the average unemployment rate, the average price level and the sum of money aggregate M1 (all 01/2007 = 100, left scale) for the GIIPS countries (Greece, Ireland, Italy, Portugal and Spain). Sources: International Financial Statistics, Eurostat.

Finally, the monetary expansion in the countries in crisis was feasible without any substantial impact on domestic inflation. ${ }^{16}$ As the additional money was used primarily to purchase goods and assets abroad, domestic prices were little affected. In Figure 3, both unemployment and domestic prices are displayed on the same (left) scale, starting at 100 . While unemployment increased by a factor of 2.5 on average, domestic prices had a cumulative increase of only about 12 percent during the same period. In fact, as the crisis has not reached the largest countries in the euro area, the central bank expansion has left the total monetary base relatively unchanged until the end of 2011. And, the aggregate increase is still not remarkably large when compared to the US Federal Reserve Bank or the Bank of England.

\subsection{A regression analysis}

In this section, we econometrically evaluate whether the comovements of central bank credit, unemployment rates and inflation are statistically significant. We estimate the central bank reaction functions of national central banks in the euro area in a panel regression analysis. ${ }^{17}$ The evidence presented is consistent

\footnotetext{
${ }^{16}$ Also in other countries inflation is still moderate at this point. When we discuss the inflation bias and the "costs in terms of inflation", we also mean the risks of future inflation that NCBs are willing to accept. The banks present holdings of excess deposits have prevented a larger inflation for the euro area as a whole so far, but certainly bear the risk that this inflation will come at a later stage, once excess deposits are withdrawn from the central banks.

${ }^{17}$ See Appendix 3 for a detailed description of the data sources.
} 
with the view that before the crisis, the central banks where primarily targeting domestic inflation, while since the beginning of the crisis, the national central banks have been targeting unemployment instead.

The execution of the empirical analysis faces several challenges. First, the time series are rather short. Secondly, there are some series that start from values close to zero, and increase in a short period to quite large numbers. In first differences, the later aspect leads to time series with initially very large growth rates, which decline over time. To avoid these data issues, we chose to estimate the subsequent regressions in log levels. Tables 1 and 2 show that estimating the linkages in levels is indeed appropriate; the variables are all non-stationary in levels and stationary in 1st differences. Furthermore, we cannot reject the null of no-cointegration. The later regression results can thus be interpreted as a cointegrating relationship among the variables. In order to address the small sample issue, we estimate all regressions as panel regressions and use monthly, seasonally adjusted data. We estimate our model using fixed effects to control for country specific effects and report robust clustered standard errors. ${ }^{18}$

Table 1: Unit Root Properties

\begin{tabular}{|c|c|c|}
\hline Variables & $\begin{array}{l}\text { Fisher type ADF with } \\
H_{0} \text { : All panels contain } \\
\text { (individual) unit roots }\end{array}$ & $\begin{array}{l}\text { Breitung LM with } \\
H_{0} \text { : Panels contain } \\
\text { (common) unit root }\end{array}$ \\
\hline NCB Credit & $14.50(0.935)$ & $-0.42(0.337)$ \\
\hline$\triangle \mathrm{NCB}$ Credit & $370.77(0.000)$ & $-24.39(0.000)$ \\
\hline HCPI & $18.45(0.780)$ & $20.37(1.000)$ \\
\hline$\Delta \mathrm{HCPI}$ & $192.40(0.000)$ & $-15.27(0.000)$ \\
\hline Unemployment & $26.81(0.313)$ & $7.09(1.000)$ \\
\hline$\Delta$ Unemployment & $103.30(0.000)$ & $-15.97(0.000)$ \\
\hline
\end{tabular}

Notes: Probability values in parentheses. Variables in logs and differenced logs, respectively. Tests have been conducted for time series from 2001 onwards to ensure balanced panels.

\footnotetext{
${ }^{18} \mathrm{An}$ F-Test confirms that the country specific constants are indeed not jointly equal to zero at the $1 \%$ level of significance. Furthermore, from a graphical analysis of the data we suspected cross-country heteroscedasticity. Indeed, a modified Wald-test rejects the null of homoscedasticity with $\chi_{12}^{2}=7523.71$ at the $1 \%$ level of significance.
} 
Table 2: Cointegration Properties

\begin{tabular}{|c|c|c|c|c|}
\hline \multirow[b]{3}{*}{ Variables } & \multicolumn{4}{|c|}{$\begin{array}{l}\text { Error correction model based test by } \\
\text { Westerlund (2007) with } H_{0} \text { : No cointegration }\end{array}$} \\
\hline & \multicolumn{2}{|c|}{$\begin{array}{l}\text { Statistics based on weighted } \\
\text { avg. of individual estimates }\end{array}$} & \multicolumn{2}{|c|}{$\begin{array}{l}\text { Statistics based on } \\
\text { pooled information }\end{array}$} \\
\hline & $G_{\tau}$ & $G_{\alpha}$ & $P_{\tau}$ & $P_{\alpha}$ \\
\hline \multicolumn{5}{|l|}{ NCB Credit, HCPI } \\
\hline \multirow[t]{2}{*}{ and Unemployment } & -2.25 & -10.11 & -7.13 & -9.17 \\
\hline & $(0.002)$ & $(0.003)$ & $(0.002)$ & $(0.000)$ \\
\hline \multirow[t]{2}{*}{ with constant } & -3.05 & -15.69 & -9.71 & -14.77 \\
\hline & $(0.000)$ & $(0.000)$ & $(0.000)$ & $(0.000)$ \\
\hline \multirow[t]{2}{*}{ with constant and trend } & -3.34 & -17.10 & -10.78 & -17.91 \\
\hline & $(0.000)$ & $(0.051)$ & $(0.001)$ & $(0.000)$ \\
\hline
\end{tabular}

Notes: Probability values in parentheses. Lags and leads have been selected using AIC. Additionally, we performed a simple Kao type cointegration test based on the residual of a regression of NCB credit on unemployment and the HCPI. An ADF test statistic of $\chi^{-1}(24)=39.89$ and a respective p-value of 0.022 indicate that the residuals indeed do not contain a unit root, thus pointing to a cointegrating relationship.

In Table 3, we present the results for our benchmark regressions. In columns 1-4, we explain the amount of credit that is awarded by the respective national central banks to domestic commercial banks, by inflation and unemployment a classical Phillips curve trade-off. Furthermore, we include a dummy variable that takes a value of 0 before the crisis and a value of 1 after the crisis. The beginning of the crisis, which marks a regime change in monetary policy, as discussed above, is identified in several ways. We use (1) the beginning of 2007, as many other authors have done in the literature. We furthermore use August 2007, where the Target2 clearing system was introduced, September 2008, where Lehman brothers collapsed and October 2008, where the ECB moved to full allotment tenders as robustness tests.

In Table 3 , the coefficients $\beta_{1}$ and $\beta_{3}$ measure the significance of the variables before the 2007 financial crisis. $\beta_{2}$ and $\beta_{4}$ measure the partial effect of each variable after the crisis - here the respective variable is interacted with the dummy variable for the crisis. Finally, the sums of $\beta_{1}+\beta_{2}$ and $\beta_{3}+\beta_{4}$ measure the total effect of each variable during the crisis period.

In the pre-crisis period, it is interesting that the central banks apparently followed an inflation target. The variable for prices is highly statistically significant, but the unemployment variable is insignificant. This is consistent with the official goal of the ECB to achieve price stability. In the aftermath of the crisis, however, this pattern appears to have changed. The F-tests in the end of Table 3 indicate that prices are no longer a significant determinant of central bank credit. On the other hand, the unemployment variable has been highly significant during this period. This evidence is consistent with the stylized facts presented above, where the graphs clearly show a positive correlation between central bank credit and unemployment in the post-2007 period. 
Table 3: Benchmark Regression and Varying Crisis Dates

\begin{tabular}{lllll}
\hline \multicolumn{2}{l}{ Dependent Variable: Central Bank Credit } & & & \\
\hline & $(1)$ & $(2)$ & $(3)$ & $(4)$ \\
Variables & Jan 07 & Aug 07 & Sep 08 & Oct 08 \\
\hline HCPI $\left(\beta_{1}\right)$ & $4.870^{* * *}$ & $4.502^{* * *}$ & $5.110^{* * *}$ & $5.282^{* * *}$ \\
& $(4.09)$ & $(3.71)$ & $(5.17)$ & $(5.37)$ \\
HCPI x Crisis Dummy $\left(\beta_{2}\right)$ & -3.454 & -7.365 & -8.652 & -8.657 \\
& $(0.58)$ & $(1.15)$ & $(1.40)$ & $(1.42)$ \\
Unemployment $\left(\beta_{3}\right)$ & 0.327 & 0.162 & 0.026 & 0.021 \\
& $(0.84)$ & $(0.41)$ & $(0.06)$ & $(0.05)$ \\
Unemployment x Crisis Dummy $\left(\beta_{4}\right)$ & $1.278^{*}$ & $1.579^{* *}$ & $1.740^{* *}$ & $1.764^{* *}$ \\
& $(1.95)$ & $(2.33)$ & $(2.43)$ & $(2.45)$ \\
Crisis Dummy & 13.885 & 31.835 & 37.499 & 37.434 \\
& $(0.50)$ & $(1.07)$ & $(1.31)$ & $(1.33)$ \\
Fixed Effects & yes & yes & yes & yes \\
\hline \hline F-test $\left(\beta_{1}+\beta_{2}=0\right)$ & 0.06 & 0.21 & 0.33 & 0.31 \\
F-test $\left(\beta_{3}+\beta_{4}=0\right)$ & $22.51^{* * *}$ & $17.53^{* * *}$ & $14.44^{* * *}$ & $14.56^{* * *}$ \\
$R^{2}($ overall) & 0.16 & 0.18 & 0.19 & 0.19 \\
Observations & 1800 & 1800 & 1800 & 1800 \\
\hline \hline
\end{tabular}

Notes: All variables in logged levels. Robust t-statistics in parentheses account for possible within- and between-cluster correlation as well as serial correlation (see e.g. Williams (2000)); *,**, *** indicate variables significant at $10 \%, 5 \%$, and $1 \%$ level respectively.

We test for the robustness of this main empirical result in several ways. First, in Table 4, we perform an outlier analysis. To see whether our results are driven by any individual countries, we re-estimate our benchmark regression above on a subset of countries that leave one of the crisis countries out of the analysis, at a time. We see that the regression coefficients and confidence intervals do not change substantially, when leaving out any individual country. 
Table 4: Outlier Analysis

\begin{tabular}{llllll}
\hline \multicolumn{2}{l}{ Dependent Variable: Central Bank Credit } & & & & \\
\hline & $(1)$ & $(2)$ & $(3)$ & $(4)$ & $(5)$ \\
Variables & GRC & IRL & ITA & PRT & ESP \\
\hline HCPI $\left(\beta_{1}\right)$ & $4.414^{* * *}$ & $4.564^{* * *}$ & $5.318^{* * *}$ & $5.564^{* * *}$ & $5.333^{* * *}$ \\
& $(3.56)$ & $(3.39)$ & $(4.13)$ & $(4.87)$ & $(3.69)$ \\
HCPI x Crisis Dummy $\left(\beta_{2}\right)$ & -6.753 & -3.333 & -4.878 & -6.005 & -3.948 \\
& $(1.11)$ & $(0.54)$ & $(0.77)$ & $(1.07)$ & $(0.64)$ \\
Unemployment $\left(\beta_{3}\right)$ & 0.501 & 0.355 & 0.263 & 0.321 & 0.246 \\
& $(1.40)$ & $(0.90)$ & $(0.64)$ & $(0.77)$ & $(0.58)$ \\
Unemployment x Crisis Dummy $\left(\beta_{4}\right)$ & 1.013 & $1.315^{*}$ & $1.305^{*}$ & $1.231^{*}$ & $1.579^{*}$ \\
& $(1.79)$ & $(1.89)$ & $(1.99)$ & $(1.86)$ & $(2.19)$ \\
Crisis Dummy & 29.829 & 13.269 & 20.462 & 25.881 & 15.623 \\
& $(1.07)$ & $(0.47)$ & $(0.70)$ & $(1.00)$ & $(0.55)$ \\
Fixed Effects & yes & yes & yes & yes & yes \\
\hline \hline F-test $\left(\beta_{1}+\beta_{2}=0\right)$ & 0.18 & 0.04 & 0.01 & 0.31 & 0.01 \\
F-test $\left(\beta_{3}+\beta_{4}=0\right)$ & $25.99^{* * *}$ & $15.52^{* * *}$ & $23.33^{* * *}$ & $14.56^{* * *}$ & $23.27^{* * *}$ \\
$R^{2}$ (overall) & 0.14 & 0.13 & 0.15 & 0.18 & 0.12 \\
Observations & 1661 & 1649 & 1649 & 1649 & 1649 \\
\hline \hline
\end{tabular}

Notes: All variables in logged levels. Robust t-statistics in parentheses account for possible withinand between-cluster correlation as well as serial correlation (e.g. Williams (2000)). *, **, *** indicate variables significant at $10 \%, 5 \%$, and $1 \%$ level respectively.

We furthermore estimate our benchmark regression with different estimation methods. In our benchmark regression we used a simple panel regression with fixed effects. In Table 5, we also implement (1) a random effects model, (2) a simple pooled OLS regression and (3) a fixed effects regression with alternative robust standard errors based on Driscoll and Kraay (1998). In our case, the additional orthogonality condition imposed in random effects models does not hold, however, as a Sargan-Hansen test based on an artificial regression approach rejects the random effects model in favor of the fixed effects model with a $\chi_{5}^{2}=$ 82.08 at the $1 \%$ level of significance.

In Columns (4) and (5) of Table 5 we present two regressions that control for endogeneity. In regression (4) we use lagged values as instruments in a 2-stage least squares regression. In regression (5), we exploit the heteroscedasticity of our data set for identification, following Lewbel (2012). Both 2SLS regressions do not seem to be under- or overidentified at the $5 \%$ level of significance as indicated by Kleibergen-Paap rk LM statistics and J-statistics, respectively. F-Statistics $>10$ in the first stage regressions additionally suggest that weak identification is not a problem either. Furthermore, a modified Wald test rejecting homoscedasticity at the $1 \%$ level in the first stage regression of column (5) indicates that the Lewbel (2012) is indeed a valid approach for our data set.

The significance levels of some coefficients changes somewhat across different estimation techniques. However, the Wald-test at the bottom of each table that measures the impact of the variables in the crisis period remains remarkably robust. 
Table 5: Different Estimation Methods

\begin{tabular}{llllll}
\hline Dependent Variable: Central Bank Credit & & & & \\
& $(1)$ & $(2)$ & $(3)$ & $(4)$ & $(5)$ \\
Variables & & & & 2SLS & 2SLS \\
& RE & P-OLS & DK & IV Set A & IV Set B \\
\hline HCPI $\left(\beta_{1}\right)$ & $4.876^{* * *}$ & $4.366^{* * *}$ & $4.870^{* * *}$ & 2.533 & $7.519^{* *}$ \\
HCPI x Crisis Dummy $\left(\beta_{2}\right)$ & $(4.10)$ & $(4.94)$ & $(6.24)$ & $(1.24)$ & $(2.27)$ \\
& -3.468 & $-6.080^{* * *}$ & 3.454 & -4.985 & -11.935 \\
Unemployment $\left(\beta_{3}\right)$ & $(0.58)$ & $(3.79)$ & $(1.28)$ & $(0.81)$ & $(0.91)$ \\
& 0.322 & -0.008 & $0.327^{* * *}$ & 0.375 & 0.240 \\
Unemployment x Crisis Dummy $\left(\beta_{4}\right)$ & $(0.82)$ & $(0.07)$ & $(2.94)$ & $(0.91)$ & $(0.53)$ \\
& $1.279^{*}$ & $1.200^{* * *}$ & $1.278^{* * *}$ & $1.073^{*}$ & $1.485^{*}$ \\
Crisis Dummy & $(1.96)$ & $(3.59)$ & $(5.24)$ & $(1.66)$ & $(1.90)$ \\
& 13.947 & $26.487^{* * *}$ & $13.885^{* * *}$ & -25.026 & 52.953 \\
\hline \hline F-test $\left(\beta_{1}+\beta_{2}=0\right)$ & $(0.51)$ & $(3.59)$ & $(1.13)$ & $(0.89)$ & $(0.88)$ \\
F-test $\left(\beta_{3}+\beta_{4}=0\right)$ & 0.06 & 1.64 & 0.32 & 2.04 & 0.18 \\
$R^{2}$ & $22.60^{* * *}$ & $110.19^{* * *}$ & $52.34^{* * *}$ & $16.43^{* * *}$ & $19.40^{* * *}$ \\
Observations & 0.16 & 0.16 & 0.16 & - & - \\
\hline \hline
\end{tabular}

Notes: All variables in logged levels. Again *, **, *** indicate variables significant at 10\%, 5\%, and 1\% level respectively. The first column shows the results of a random effects model with the same robust t-statistics used in the benchmark regression. Column (2) shows a simple pooled OLS regression. Column (3) presents a fixed effects regression with Driscoll and Kraay (1998) standard errors. Column (4) presents a 2SLS regression using the first lagged value of the explanatory variables as instruments. Additionally, column (5) uses instruments based on the Lewbel (2012) identification approach.

\section{$5 \quad$ Related literature}

A natural area of application of the common-pool problem approach in macroeconomics has been the use of common-tax-pools in fiscal policy. Weingast, Shepsle and Johnson (1981) apply a version for the common-pool problem to the inefficiency of regional fiscal distributions by arguing that whenever central parliaments decide on the funding of regional projects an overspending bias will arise. This is the case since the members of parliaments are elected from certain regional areas and as such overvalue the interest of these regions. From the regional perspective the benefits of a locally executed project, which is funded by the central budget, will always be overvalued since the full marginal benefit of the project for the region is not weighed against the full marginal costs of the project, but rather against the costs covered by the region, which is only a negligible portion of the full costs.

Alesina and Drazen (1991) take the interpretation of the common pool problem of fiscal policy further. They argue that the common-pool problem is not only a potential source of fiscal instability, but it is also at the core of delayed fiscal stabilization. This conclusion is based on applying the common-pool prob- 
lem in a political economy framework with heterogeneous groups, where delayed fiscal stabilization is modeled as the result of disagreements upon the distribution of the costs and benefits of stabilization.

The common-pool problem issues of fiscal policy have also been extensively studied with regard to the functioning of fiscal unions (see Knight (2003) and Alesina \& Perotti (1999) for detailed discussions of studies documenting the common-tax pool problem and proposed solutions). With this regard the common-pool problem has typically been employed in the analysis of the funding of infrastructure or other locally used public goods where a large portion of the benefits stays within one member of the union, while the costs are symmetrically distributed across all participants (Basley \& Coate (2003)). The objects of the analysis in this strand of the literature have been examples for public overspending from around the world ranging from the US (Feldstein \& Vaillant (1998)) and the European Union (e.g. Hallerberg \& von Hagen (1999)) to developing countries (e.g. Kletzer \& Singh (1997) and Hausmann \& Purfield (2004)).

In the years following the decision for the establishment of the European Monetary Union a broad strand of the literature has been focused on the analysis of fiscal common-pools problems in the European Union. One strand of this literature focused on the interaction between the loss of monetary and fiscal stabilizers in the framework of the monetary union (Gali \& Perotti (2003)). Another strand of this literature has been concerned with analyzing whether the existence of common currency will generate bail-out expectations for countries in fiscal distress and thus aggravate the standard common-pool problem (von Hagen \& Eichengreen (1996), Chari \& Kehoe (2004), Krogstrup \& Wyplosz (2010)). These studies recognize that if the fiscal issues arising from the common-pool problem are not successfully solved these would generate incentives to jeopardize monetary policy stability, since in this case the ECB is forced to accommodate the lax fiscal policy and engage in bail-outs as we observe now. However, this literature has so far assumed that the ECB will keep its ability and willingness to perform uniform monetary policy, so that even if a bail-out is decided the limits and the conditions of the bail-out will be determined by the ECB. As we discussed above the recent undermining of the ECB's institutional setting has raised substantial concerns about whether this is indeed the case. In particular, individual member countries have been given the opportunity to modify the stance of the Union's monetary policy which in turn has created incentives to apply monetary policy tools such as central bank's credit to commercial banks in a way that is prone to the emergence of common-pool type externalities.

This common-pool distortion of the incentives to create inflation has so far only been discussed by Aizenman (1992), Casella (1992) and von Hagen and Süppel (1994). Similar to the set-up analyzed in our paper Aizenman shows that the inflationary bias will be high if the optimal inflation rate is set by several decision makers rather than by a centralized decision maker. We generally come to a similar conclusion with regard to inflationary biases as Aizenman (1992). However, our approach differs from his in that we focus on the trade-off between the benefits of credit expansion and costs of inflation, while Aizenman (1992) is 
concerned with the optimality of inflation tax from a Laffer curve perspective. Casella (1992) and von Hagen and Süppel (1994) discuss how the inflationary bias depends on the decision structure of the monetary union's central bank. While in our framework we allow for completely decentralized monetary policy within the union, these authors assume common monetary policy and discuss, which is the optimal design of the decision about these common monetary policy rules and what are the incentives of countries with small impact on the monetary decision making process to participate in the union.

The possibility of exploiting the ECB monetary policy tools as a commonpool has only been analyzed by few works, none of which explicitly covers inflation biases. In a policy paper Tornell and Westermann (2012a, 2012b) suggest that the implicit bank bail-outs given by the lax monetary policy and emergency funding in the euro area are an example for the common-pool problem, since each of the regional banking supervisor can (at least in the short-run) achieve the benefit of not having to bear the costs of bank liquidations, while it's paying only a minor share of the costs generated by the explosion of central bank's credit to the banking sector. Buiter (2012) presents a detailed review of the current ECB institutional framework and draws parallels between the rouble union and the current ECB policy. Further, Tornell (2012) discusses the emergence of overwhelming TARGET2 balances as an expression of the common-pool problem. He presents a formal general-equilibrium model on the political economy of TARGET2 balances.

Finally, our paper is reminiscent of the competition among bank regulators that has been modeled by Sinn (2003). While Sinn models the race-tothe-bottom with regard to capital-ratios, illustrating that national regulators neglect the external effect on other countries, his model could be extended to the decision of whether or not a bank is classified "solvent", or the quality of collateral acceptable for central bank refinancing.

\section{Conclusions}

In this paper we show how a tragedy-of-commons, stemming from the institutional shortcomings of the European Monetary Union, gives rise to excess central bank credit and an increased inflation bias.

We present a brief description of the institutional features of the EMU. We then discuss the inflation effects in the framework of a simple model of monetary policy where the central bank minimizes a loss function with two arguments: the output gap and inflation. We add two new elements two this model. First, we directly include a credit channel effect: the central bank can generate positive output changes by expanding credit to domestic banks. Second, we model the common-pool problem by assuming that while the positive credit channel effects are fully appropriated at "home" the inflation biases generated by the credit extensions and the increased money supply are shared across all union members.

We support the tragedy-of-commons argument and the implications of the theoretical model by presenting an empirical examination of the dynamics of 
central bank's credit, monetary aggregates and unemployment in the EMU. Plotting the dynamics of these variables we first graphically show the abrupt expansion of central bank credit in some EMU countries, which correlates with unemployment, has not increased money supply and inflation in these countries. Finally, by estimating the central bank's reaction functions to inflation and unemployment we show that starting from 2007/8 a significant shift of central bank's objectives was observed.

The monetary policy common-pool problems presented in this paper illustrate the need for an institutional reform of the Union. Applying the implications of the literature focused on fiscal common pools problems to the area of monetary policy common-pool problems discussed in this paper would suggest that creating a stronger institutional framework, which is able to endogenize the externalities of excessive monetary policy expansion, is essential. In particular, a centralized decision making process about the key features of monetary policy and a uniform implementation of this policy can help mitigate the problems arising from the common-pool incentives to access central bank's credit. These should include both a centralized decision making about the solvency of banks, as well as going back to a uniform catalogue of eligible collateral.

\section{References}

[1] Aizenman, Joshua, 1992, "Competitive Externalities and the Optimal Seigniorage", Journal of Money, Credit and Banking, 24(1), 61-71.

[2] Alesina, Alberto \& Alan Drazen, 1991, "Why are Stabilizations Delayed?", American Economic Review, 82, 1170-1188.

[3] Alesina, Alberto \& Roberto Perotti, 1999, "Budget Deficits and Budget Institutions", In: "Fiscal Institutions and Fiscal Performance", Poterba, James M. \& Jürgen von Hagen (eds.), University of Chicago Press.

[4] Basley, Timothy \& Stephen Coate, 2003, "Centralized vs Decentralized Provision of Local Public Goods: A political Economy Analysis", Journal of Public Economics, 87, 2611- 2637.

[5] Barro, Robert J. \& David B.Gordon, 1983, "Rules, Discretion and Reputation in a Model of Monetary Policy", Journal of Monetary Economics, 12, $101-121$

[6] Bernanke, Ben S., Mark Gertler \& Simon Gilchrist, 2000, "The Financial Accelerator in a Quantitative Business Cycle Framework", In: "Handook of Macroeconomics", Taylor and Woodford (ed), 1341-1393.

[7] Buiter, Willem, 2012, "Is the Eurozone at Risk of turning into the Rouble Zone?", Citi Economics, Global Economics View, London, February 13th. 
[8] Casella, Alessandra, 1992, "Participation in a Currency Union", American Economic Review, 82(4), 847-863.

[9] Chari, Varadarajan V. \& Patrick J. Kehoe, 2008, "Time Inconsistency and Free-Riding in a Monetary Union", Journal of Money, Credit and Banking, 40, 1329-1356.

[10] Driscoll, John C. \& Aart C. Kraay, 1998, "Consistent Covariance Matrix Estimation With Spatially Dependent Panel Data,", The Review of Economics and Statistics, 80(4), 549-560.

[11] Feldstein, Martin \& Marian Vaillant, 1998, "Can state taxes redistribute income?", Journal of Public Economics, 68(3), 369-396.

[12] Galí Jordi \& Roberto Perotti 2003, "Fiscal Policy and Monetary Integration in Europe", Economic Policy, 18(37), 533-572.

[13] Garber, Peter M., 1999, "The target mechanism: Will it propagate or stifle a stage III crisis?", Carnegie-Rochester Conference Series on Public Policy, 51(1), 1999.

[14] Hallerberg, Mark \& Jürgen von Hagen, 1999, "Electoral Institutions, Cabinet Negotiations, and Budget Deficits within the European Union", In: "Fiscal Institutions and Fiscal Performance", Poterba, James \& Jürgen von Hagen (eds.), University of Chicago Press, 209-232.

[15] Hausmann, Ricardo \& Catriona M. Purfield, 2004, "The Challenge of Fiscal Adjustment in a Democracy: The Case of India", IMF Working Paper 04/168, September.

[16] Kashyap, Anil K., Jeremy C. Stein \& David W. Wilcox, 1993, "Monetary Policy and Credit Conditions: Evidence From the Composition of External Finance", American Economic Review, 83, 78-98.

[17] Kletzer, Kenneth M \& Nirvikar Singh, 1997, "The political economy of Indian fiscal federalism", In: "Fiscal Policies in India", Mundle, Sudipto (ed.), Oxford University Press,

[18] Knight, Brian, 2003, "Common Tax Pool Problems in Federal Systems", In: "Democratic Constitutional Design and Policy", Roger D. Congelton \& Birgitta Swedenborg (eds.), MIT Press, 229-47.

[19] Krogstrup, Signe \& Charles Wyplosz, 2010, "A common pool theory of supranational deficit ceilings", European Economic Review, 54(2), 269278.

[20] Lewbel, Arthur, 2012, "Using Heteroscedasticity to Identify and Estimate Mismeasured and Endogenous Regressor Models", Journal of Business \& Economic Statistics, 30(1), 67-80. 
[21] Sachs, Jeffrey, Aaron Tornell \& Andres Velasco, 1996, "The Collapse of the Mexican Peso: What Have we Learned?", Economic Policy, 11(22), 13-63.

[22] Sinn, Hans-Werner, 2003, "Risktaking, Limited Liability, and the Competition of Bank Regulators", FinanzArchiv / Public Finance Analysis, 59(3), 305-329.

[23] Sinn, Hans-Werner \& Timo Wollmershäuser, 2012, "Target Loans, Current Account Balances and Capital Flows. The ECB's Rescue Facility", International Tax and Public Finance, 19(4), 468-508.

[24] Steinkamp, Sven \& Frank Westermann, 2012, "On Creditor Seniority and Sovereign Bond Prices in Europe", CESifo Woking Paper No. 3944.

[25] Tornell, Aaron \& Frank Westermann, 2005, "Boom-Bust Cycles and Financial Liberalization", MIT Press.

[26] Tornell, Aaron \& Frank Westermann, 2012a, "The Tragedy-of-theCommons at the European Central Bank and the Next Rescue Operation", VOXeu.org.

[27] Tornell, Aaron \& Frank Westermann, 2012b, "Europe Needs a Federal Reserve", The New York Times, June 20.

[28] Tornell, Aaron, 2012, "The Dynamic Tragedy-of-the-Commons in the Eurozone, the ECB and Target2 Imbalances", UCLA mimeo, September.

[29] Von Hagen, Jürgen \& Ralph Süppel, 1994,"Central Bank Constitutions for Federal Monetary Unions", European Economic Review, 38(3-4), 774-782.

[30] Von Hagen, Jürgen \& Ian Harden, 1995, "Budget Processes and Commitment to Fiscal Discipline", European Economic Review, 39, 771-79.

[31] Von Hagen, Jürgen \& Barry Eichengreen, 1996, "Federalism, Fiscal Restraints and European Monetary Union", American Economic Review, 82(2), 134-138.

[32] Walsh, Carl E., 2010, "Monetary theory and policy", 3. ed., MIT Press.

[33] Weingast, Barry, Kenneth Shepsle \& Christopher Johnson, 1981, "The Political Economy of Benefits and Costs: A Neoclassical Approach to Distributive Politics", Journal of Political Economy, 96, 132-163.

[34] Williams, Rick. L., 2000,."A Note on Robust Variance Estimation for Cluster-Correlated Data", Biometrics, 56, 645-646. 


\section{Appendix 1: The interaction with a Barro- Gordon time inconsistency problem}

In this appendix we analyze the interaction between the two new elements - a credit channel and a common pool problem - with the standard time inconsistency problem that derives from the Phillips curve trade-off in a Barro-Gordon setting. We show that the results presented above are independent from this other classical inflation bias in the literature.

\subsection{A single country}

We keep the notation as above, and add the expectation about future inflation denoted by $\pi^{e}$. The utility function and production in a single country are as follows:

$$
\begin{aligned}
& U(y, \pi)=\lambda\left(y-\overline{y_{n}}\right)-\frac{1}{2} \pi^{2} \\
& y=\overline{y_{n}}+\alpha\left(\pi-\pi^{e}\right)+y_{c}(\Delta d)
\end{aligned}
$$

with $\frac{\partial y}{\partial \Delta m}>0$ and $\Delta m=\Delta d$. Furthermore, we assume that agents are characterized by rational expectations.

Lemma 3 In a single country with a Barro-Gordon time inconsistency problem and a credit channel of monetary policy, the inflation bias is: $\lambda\left(\alpha+\frac{\partial y}{\partial \Delta m}\right)$

Proof. $\arg \max _{\Delta m} U=\lambda\left(\alpha\left(\Delta m-\pi^{e}\right)+y_{c}(\Delta m)\right)-\frac{1}{2} \Delta m^{2} ; \frac{\partial U}{\partial \Delta m}=\lambda\left(\alpha+\frac{\partial y}{\partial \Delta m}\right)-$ $\Delta m ; \Delta m^{*}=\lambda\left(\alpha+\frac{\partial y}{\partial \Delta m}\right)$

The optimal inflation $\Delta m^{*}=\lambda\left(\alpha+\frac{\partial y}{\partial \Delta m}\right)$ is larger than zero, and larger than the standard Barro-Gordon result, which is $\Delta m^{*}=\lambda \alpha$ in the simple setting. The existence of a credit channel adds a further motive to conduct expansionary monetary policy.

\subsection{Currency union}

Now consider, again, the same setup for a currency union. Utility and production functions are given as follows:

$$
\begin{gathered}
U\left(y_{i}, \pi_{i}\right)=\lambda\left(y_{i}-\overline{y_{n}}\right)-\frac{1}{2} \pi_{i}^{2} \\
y_{i}=\overline{y_{n}}+\alpha\left(\pi_{i}-\pi^{e}\right)+y_{c, i}\left(\Delta d_{i}\right)
\end{gathered}
$$

with $\frac{\partial y_{i}}{\partial \Delta m_{i}}>0$. We make the same assumptions as above, namely, $\pi_{i}=\pi$, 
due to the law of one price and $\pi=\frac{1}{n} \sum_{i=1}^{n} \Delta m_{i}$, as well as $\Delta m_{i}=\Delta d_{i}$.

Proposition 4 In a currency union with a Barro-Gordon time inconsistency problem and a credit channel of monetary policy, the inflation bias is larger than in a single country

Proof. $\arg \max _{\Delta m_{i}} U_{i}=\lambda\left(\alpha\left(\frac{1}{n} \sum_{i=1}^{n} \Delta m_{i}-\pi^{e}\right)+y_{c}\left(\Delta m_{i}\right)\right)-\frac{1}{2}\left(\frac{1}{n} \sum_{i=1}^{n} \Delta m_{i}\right)^{2} ; \frac{\partial U_{i}}{\partial \Delta m_{i}}=$ $\frac{1}{n^{2}}\left(\sum_{\substack{j=1 \\ j \neq i}}^{n} \Delta m_{j}-n^{2} \frac{\partial y_{i}}{\partial \Delta m_{i}} \lambda-n \alpha \lambda+\Delta m_{i}\right) ; \Delta m_{i}^{*}=n \lambda\left(\alpha+n \frac{\partial y_{i}}{\partial \Delta m_{i}}\right)-\sum_{\substack{j=1 \\ j \neq i}}^{n} \Delta m_{j} ;$ In symmetric equilibrium: $\Delta m^{*}=\lambda\left(\alpha+n \frac{\partial y}{\partial \Delta m}\right) ; \lambda\left(\alpha+n \frac{\partial y}{\partial \Delta m}\right)-\lambda\left(\alpha+\frac{\partial y}{\partial \Delta m}\right)=$ $\frac{\partial y}{\partial \Delta m} \lambda(n-1)>0$

The inflation in equilibrium will be $\Delta m^{*}=\lambda\left(\alpha+n \frac{\partial y}{\partial \Delta m}\right)$. Note that the original Barro-Gordon inflation bias is unaffected by our extensions. When comparing the optimal inflation rate in the currency union of the main paper (without Barro-Gordon) and the appendix, we get exactly the standard inflation bias explaining the difference:

Corollary 5 The tragedy of the commons does not affect the Barro-Gordon time inconsistency bias

Proof. In a currency union without time inconsistency problem: $\Delta m_{i}^{*}=$ $n \lambda \frac{\partial y_{i}}{\partial \Delta m_{i}} ;$ In a currency union with time inconsistency problem: $\Delta m^{*}=\lambda(\alpha+$ $\left.n \frac{\partial y}{\partial \Delta m}\right) ; n \lambda \frac{\partial y_{i}}{\partial \Delta m_{i}}-\lambda\left(\alpha+n \frac{\partial y}{\partial \Delta m}\right)=\lambda \alpha$

The intuition for this corollary can be illustrated by analyzing the effect of a currency union on the marginal cost and benefit from inflation. As the benefits from inflation in the Barro-Gordon model derive from the impact of inflation on wages, the currency union will not affect the trade-off between the output and inflation. Printing more money will be associated with the average cost in terms of inflation, as above. But it will also lead only to the average benefit. As both are aligned, there is no additional incentive for printing money to make use of the Phillips-curve trade off. 


\section{Appendix 2: Country-level figures}

Figure 4: Central Bank Credit and Unemployment

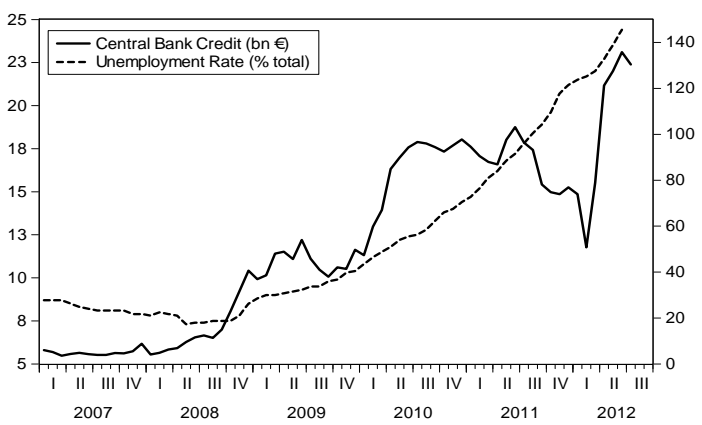

Greece

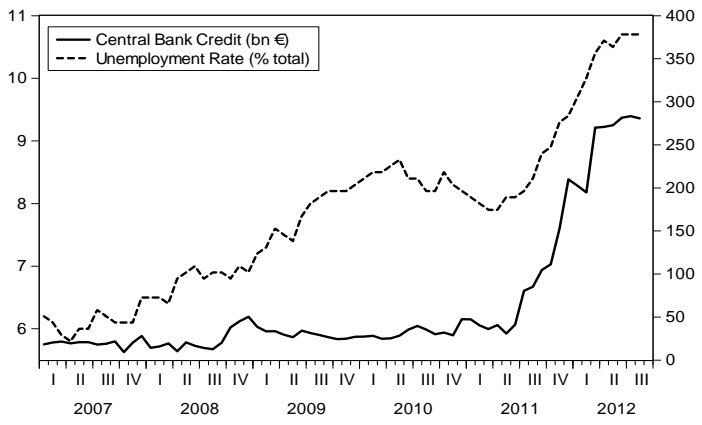

Italy

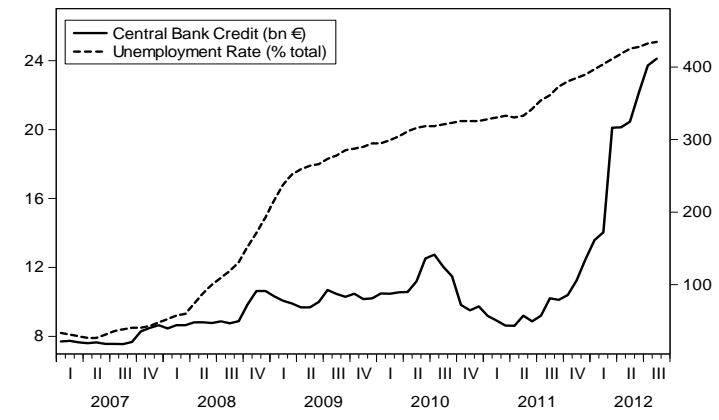

Spain

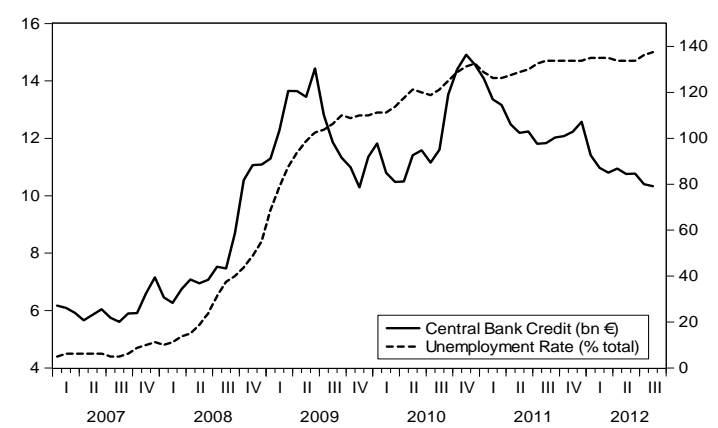

Ireland

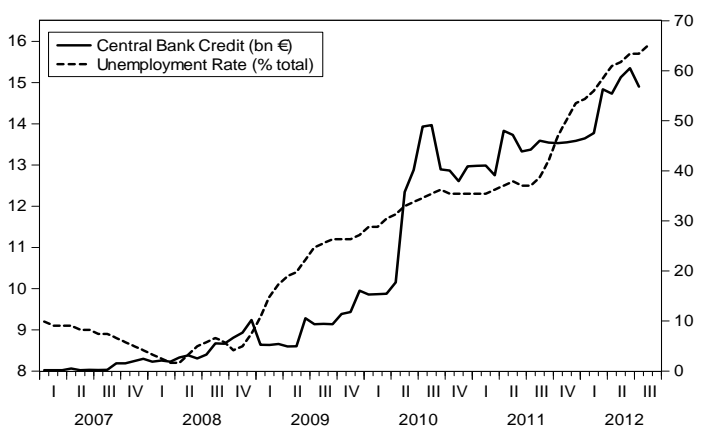

Portugal

Notes: Figures show the credit of national central banks (bn €, right scale) versus the total unemployment rate (\%, left scale) for the GIIPS countries (Greece, Ireland, Italy, Portugal and Spain). Sources: International Financial Statistics, Euro Crisis Monitor, Eurostat. 
Figure 5: Central Bank Credit and Total Bank Lending

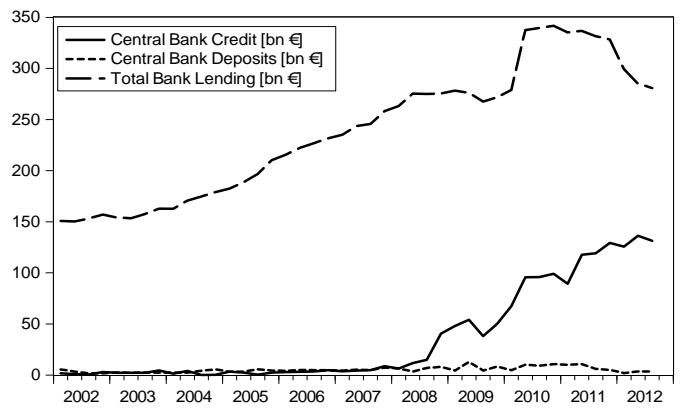

Greece

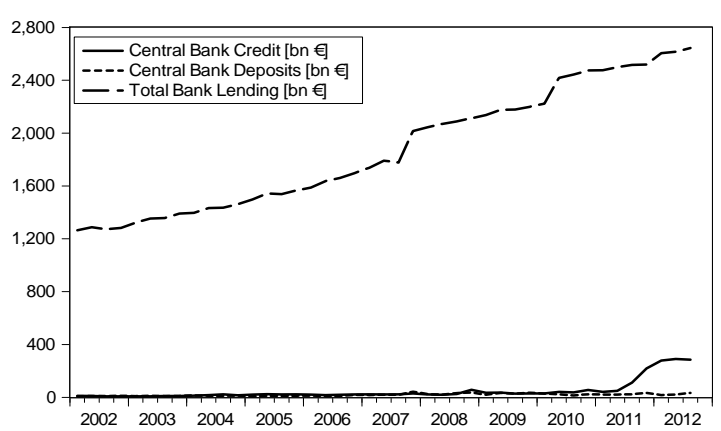

Italy

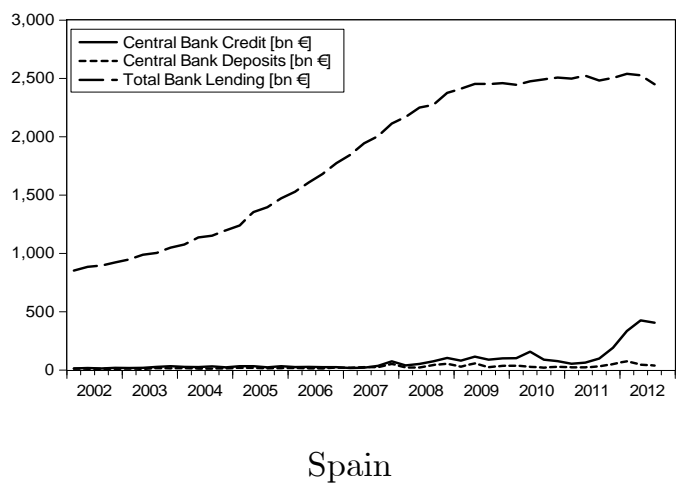

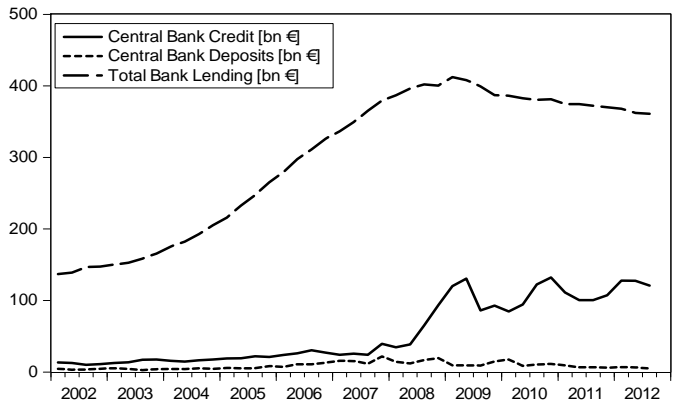

Ireland

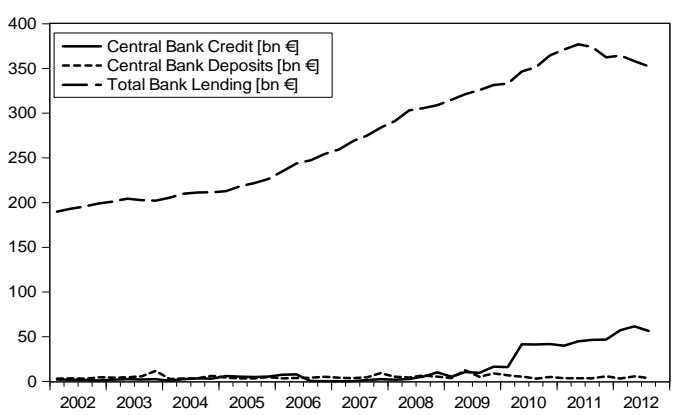

Portugal

Notes: Figures show the credit of national central banks, the deposits of national central banks and the bank lending of the national monetary financial instiutions (in bn $€$ ) for the GIIPS countries (Greece, Ireland, Italy,Portugal and Spain). Sources: International Financial Statistics 


\section{Appendix 3: Data sources}

Table 6: Data Sources

\begin{tabular}{|c|c|c|}
\hline Time Series & Source & Code/Name \\
\hline Unemployment & Eurostat & une_rt_m \\
\hline \multicolumn{3}{|l|}{ Harmonized Consumer } \\
\hline Price Index (HCPI) & Eurostat & prc_hicp_midx \\
\hline TARGET2 Balances & Euro Crisis Monitor (see Steinkamp \& & Westermann $(2012))$ \\
\hline Central Bank Credit & IFS, Central Bank Survey & 12E..ZK \\
\hline Central Bank Deposits & IFS, Central Bank Survey & 14C..ZK \\
\hline Total Bank Lending & IFS, Depository Corporations Survey & 32A..ZK, 32S..ZK \\
\hline Monetary aggregate M1 & Datastream (National Central Banks) & National contribution to M1 \\
\hline
\end{tabular}

Notes: Our regression analysis focuses on the member countries of the euro area, which joined the common currency before 2007 and for which data are available (i.e. Austria, Belgium, Finland, France, Germany, Greece, Ireland, Italy, Luxembourg, Netherlands, Portugal, Spain). For Greece data are from $01 / 2001$ onwards, for all other countries the series are available from 01/2000 until 07/2012. 